\title{
THE NEEDS AND UNIQUE PROBLEMS FACING SPINAL CORD INJURED PERSONS AFTER LIMB AMPUTATION
}

\author{
By A. Ohry ${ }^{\star}$, M.D., M. Heim, M.B. ChB., T. V. Steinbach, M.D. and \\ R. Rozin, M.D. \\ The Rehabilitation Centre, The Chaim Sheba Medical Centre, Tel Hashomer and \\ Sackler School of Medicine, Tel Aviv University, Israel
}

\begin{abstract}
Among hundreds of spinal cord injured patients (SCIP) who have been rehabilitated in the Sir Ludwig Guttmann Spinal Cord Injury Unit at the Sheba Medical Centre, Tel Hashomer; we only found six patients who had lost one or more limbs (upper or lower limbs). Although many plastic and orthopaedic surgeons regard paralytic limbs as useless appendages, we cannot agree with this erroneous viewpoint and we find that the clinical and psychological effects of the absence of $\operatorname{limb}(\mathrm{s})$ are tremendous. The six case reports are given together with a brief review of the relevant literature.
\end{abstract}

Key words: Spinal cord injury; Amputation; Rehabilitation; Phantom pain.

MANY orthopaedic and plastic surgeons regard paralysed limbs as useless appendages and view limb amputation as beneficial to the patient (Georgiads et al., I956; Spira et al., I963; Weeks et al., 1968). This practice has occasionally transformed the previously anaesthetic limb into a painful stump, transmitting phantom pains. The literature relating to limb amputation in spinal cord injured patients (SCIP) is scarce. Limb amputation results in sedentary instability, the unequal weight distribution causing backache and lending itself to pressure sore formation. Upper limb amputation further limits activities of daily living (ADL) and so further stunts the patients' independence, thus further destroying the body image and self concept in the light of this additional compounded disability. Guttmann, I976, stressed that the indications for amputation in SCIP should be identical to that in other non-spinal cord injured patients. Michaelis, I964; and Stewart and Comarr, I97 I, commented on amputation in general terms only. Our experience has been gained from six patients treated in our centre.

\section{Case Reports}

Case 1. A young male had an epileptic fit and fell into a mechanism of a combined harvester machine. This multitrauma resulted in a L2 conus lesion; and he lost his right upper limb above the elbow and the lower limb through the knee. The lower left limb was lost below the knee. Six years later the patient used a one arm operated wheelchair, triggers his own upper motor neurone bladder, and is independent in dressing and transferring from bed to chair to car.

Case 2. A young man was accidently shot in the neck resulting in a paralysis of the left side $\left(\mathrm{C}_{4}, 5\right)$ and the right side $\left(\mathrm{C}_{5}, 6\right)$. His left upper limb was amputated

^Correspondence: Dr A. Ohry, Sir Ludwig Guttmann Spinal Čord Injury Unit, The Neurological Rehabilitation Dept., The Chaim Sheba Medical Centre, Tel Hashomer, Israel. 
having been judged useless; and it was hoped that a prosthetic limb, operated by the contralateral shoulder, would be more beneficial. The patient has a chronic painful stump with phantom pains.

Case 3. A young man was involved in a motor vehicle accident which resulted in a D ro spastic paraplegia. He suffered severe depression which was unresponsive to medical treatment and hindered co-operation thus resulting in repeated gluteal and trochanteric pressure sores. Surgical repairs using multiple flaps did not prevent osteomyelitis of the femur and hip joint, and a life threatening sepsis required limb disarticulation. Four months after surgery, the wound which contains much fibrotic scar tissue from previous surgery, is still not completely healed.

Case 4. A 30-year-old male was involved in a motor vehicle accident resulting in a complete Di2 paraplegia and the loss of the left leg, high above the knee. In order to maintain balance the patient has to lean to the left in his wheelchair, thus increasing the pressure on his left gluteal area. Ten years after the accident the patient still has phantom pains and suffers from a feeling of inequality with his peer group because of his unusual sitting position.

Case 5. A 25-year-old chronic schizophrenic, jumped from a building resulting in a complete cauda equina lesion and multiple compound cumminuted fractures of the left tibia and fibula. Internal fixation of the fractures failed owing to deep wound infection (Ohry et al., 1977), and a lower leg amputation was carried out after all conservative medical treatment failed to arrest the infection. The patient is independent in the activities of daily living (ADL).

Case 6. A 40-year-old female was struck by the rotating blades of a windmill. The injury resulted in a complete $\mathrm{D}_{4}$ paraplegia and the necessity to amputate the left arm above the elbow. She is partially independent in ADL, uses a hemiplegia wheelchair, and she has phantom pains.

Six cases have been briefly presented to demonstrate the variations and dangers of random surgery. Case I describes a three limb amputation patient who has adjusted well to his severe disability in spite of tremendous difficulties. Case 2 highlights the incorrect treatment of a 'useless limb' and demonstrates how this initially painless limb has been transformed into a sensitive stump unable to operate a prosthesis and causing the patient severe phantom pain. Cases 3 and 6 demonstrate that although the indications for surgery and a successful result. Case 4 emphasises the problem of backache and sedentary stability and the inability of the patient to adapt to his altered form.

\section{Discussion}

In discussing the question of amputation in spinal cord injured patients, one must differentiate between upper and lower limb as well as considering the level of the cord injury. For example, the integrity of the arms in patients with a cauda equina lesion will greatly differentiate between successful independent rehabilitation and an almost totally dependent patient.

Body image in almost all SCIP is altered and the addition of a limb amputation has not only physically slowed down rehabilitation but has 
required more intensive and prolonged psychotherapy (Stauffer, I977; and Friedland, I968). A new concept was introduced when Michaelis, I964, and Guttmann, I976, pleaded for rational criteria when considering limb amputations in spinal cord injured patients. A paralysed anaesthetic limb, although apparently cumbersome, is undoubtedly preferable to postsurgical phantom pain (Bors, I963). Prior to this new rational approach, 'useless' limb amputation or disarticulation was rationalised in that this procedure produced weight reduction, easier transfer from bed to chair and avoided deforming reflex spasm (Spira et al., I963). Furthermore the infected pressure sores around the knees and ankles would not occur, and the skin and muscle from the posterior aspect of the thigh could be used to repair gluteal pressure sores. Knee and hip disarticulation was preferred to amputation levels resulting in a longer articular stump which was more prone to pressure sores owing to the inevitable flexion contracture of the joint.

In our hands limb prosthesis has proved to be a total failure. Limb amputation undoubtedly affects the sedentary stability of the SCIP. It was noted that patients tend to tilt themselves towards the healthy side resulting in scoliosis and back pain. This unequal weight distribution increases the incidence of ischial pressure sores. Limb amputation is a severe disabling procedure especially to SCIP. The phrase 'useless limb' in our opinion should never be used for it cannot in any way be equated to a paralysed limb.

\section{SUMMARY}

Amputation of the upper or lower (or of both) limbs in the traumatic spinal cord injured patient is usually a tremendous blow to body image. Also, the possible complications are numerous: apart from the psychological damage, we found imbalance, phantom pain, pressure sore formation, low back pain and difficulties in activities of daily living. According to our experience with SCIP who lost one or more of their upper or lower extremities, we can conclude that paralytic limbs are by no means 'useless appendages', as some plastic and orthopaedic surgeons claim. The indications for elective limb amputation are the same as for non-paralysed persons. In cases in which amputation occurred during the initial trauma, the rehabilitation programme must be adapated accordingly.

\section{RÉSUMÉ}

L'amputation d'un ou des deux membres inférieurs our supérieurs chez le blessé de la moelle epiniere constitue en general une grave atteinte a L'image de l'integrité de sou corps. De plus, les complications possibles sont nombreuses: àpart les troubles psychologiques, nous arons trouvé des manques de stabilites mechaniques, des doulers 'phantomes', la formation d'excarres, des douleurs lombaires et des difficultés dans leur activites quotidiennes.

Selon notre expérience avec des blessés de la moelle ayant perdu une ou deux extremités inferieurs ou supérieurs, nous sommes eu mesure de conclure que les membres paralysés ne sont pas des 'appendices inutiles' comme le pensent certains orthopèdes ou chirugieurs plastique. Les indications d'une amputation élective sont les mêmes que pour une personne non paralysée. Dans les cas ou l'amputation a eu lieu au cours du traumatisme initial, le programme de reéadaptation devra être modifie eu conséquence. 


\section{ZUSAMMENFASSUNG}

Die Amputierung eines oder beider unteren oder oberen Glieder bei traumatischen Rückenmarkverletzten ist fast immer ein Schwerer Schock für die Selbstvorstellung des Patienten. Es gibt auch viele mögliche komplikationen: ausser dem psychologischen Schaden, fanden wir schlechtes Gleichgewicht, Phantom Schmerz, Escharen, Lendenschmerzen und Schwiengkeiten in der Erfüllung täglicher Aufgaben. Nach unserer Erfahrung mit Rückenmarkverletzten die ein oder mehr untere oder obere Glieder verloren haben, kommen wir zur Schlussfolgerung dass die gelähmten Glieder keineswegs 'unnötige Fortsätze' sind, wie es manche platische oder orthopädische Chirurgen behaupten. Die Vorschriften für eine Wahlamputierung sind die selben wie für eine ungelähmte Person. In den Fällen wo die Amputierung gleichzeitig mit der Anfangstrauma Stattfand, muss das Rehabilitationsprogramm dementsprechend verändertwerden.

\section{REFERENCES}

Bors, E. (1963). Phantom limbs in patients with spinal cord injury, in spinal injuries; proceedings of a symposium, Ed. by P. Harris, Edinburgh, The Royal College of Surgeons of Edinburgh, p. I5.

FRIEDLAND, F. (1968). Rehabilitation in spinal cord injuries, chapter 17, in Rehabilitation and Medicine. Ed. by S. Licht, Maryland, E. Licht. p. 478-479.

Georgiads, N., Pickerell, K. \& Maguire, C. (I956). Total thigh flaps for extensive decubitus ulcers. Plast. Reconstr. Surg., 17, 220-225.

GuttmanN, L. (1976). Spinal cord injuries. Ed. 2, Oxford, Blackwell, p. 54I.

Michaelis, L. S. (1964). Orthopedic surgery of the limbs in paraplegia. Berlin, Springer Verlag, p. 50.

Ohry, A., Brooks, M. E., Steinbach, T. \& Rozin R. (I977). Osteomyelitis caused by mycobacterium fortuitum. Infection, $5,46-48$.

SPIRA, M. \& HARDY, S. B. (1963). Our experience with high third amputation in paraplegia. Plast. Reconstr. Surg., 31, 344-352.

STAUFFER, E. S. (I 977). Long term management of traumatic quadriplegia. Chapter 3 in the total care of spinal cord injury. Ed. by P. S. Pierce and V. H. Nickel. Boston, Little Brown, and Co.

Stewart, J. C. \& COMARR, A. E. (I97I). Disarticulation of lower extremity in spinal cord injury patients, a 25 years review, 2800 patients, proceedings of the I8th VA spinal cord injury conference, 5-7 October. Boston, Mass. p. 20-73.

WeEks, P. M. \& BROWER, T. D. (I968). Island flaps coverage of extensive decubitus ulcers. Plast. Reconstr. Surg., 42, 422-436. 